\title{
The Impact of Dividend Policy, Ownership Structure and Capital Structure on Company Valuation of Indonesian Manufacture
}

\author{
Munajat Mubaraq ${ }^{1}$ Suhadak $^{2}$ Sri Mangesti Rahayu ${ }^{2}$ Ari Darmawan $^{3} \quad$ Muhammad Saifi $^{3}$ \\ 1.Doctoral Program of Businness Administration, Brawijaya University Malang, Indonesia \\ 2.Professor - Doctoral Program of Business Administration, Brawijaya University, Malang, Indonesia \\ 3.Lecturer - Doctoral Program of Business Administration, Brawijaya University, Malang, Indonesia
}

\begin{abstract}
This research aims to examine how dividend policy considerations, ownership structure and capital structure theoretically and empirically affect firm value. Manufacturing sector companies listed as research samples on the Stock Exchange in Indonesia for 2014-2018. In general, the results of the study indicate that there is a significant and positive influence of dividend policy on firm value, which means that the higher dividend policy will level up firm value. There is no significant effect of Ownership Structure on Firm value. There is no significant effect of Capital Structure on Firm value.
\end{abstract}

Keywords: Dividend Policy, Ownership Structure, Capital Structure, Firm value

DOI: $10.7176 /$ RJFA/11-17-18

Publication date:October $31^{\text {st }} 2020$

\section{Introduction}

The company's aim is to optimize firm value, and firm value is determined by the company's internal and external factors. The decision making of financial management, all investment decisions, financing decisions and dividend policies are based on the company's objective of growing firm value. But not all empirical research has found that financial management decisions are influenced by corporate value. Some empiricism about the impact on firm value of ownership structure, capital structure and dividend policies also shows different results.

Previous researchers have examined several determinants of Firm value. Meca (2011) examine the effects of multiple dimensions of ownership structure on Tobin's Q in Spain, to represent conflicting interests: Ownership Concentration, Insider Ownership and Bank Ownership. The study results show that the ownership structure mechanism that affects firm value is ownership concentration. The findings show that ownership concentration positively affects firm value, but at a high level it can cause an adverse effect, market valuation will be negatively affected by the high level of ownership of large shareholders. Furthermore, Saifi et al. (2015) show that the dividend policy in the form of Dividend per Share, Dividend Equity Ratio and Dividend Yield has a significant positive effect on firm value with indicators of Price Earnings Ratio and Tobin's Q.

The effect of dividend policy on Firm value is explained through Myron Gordon and John Lintner (1959). Bird-in-the-hand theory states that investors feel safer to earn income in the form of dividend payments rather than waiting for capital gains, where dividend distribution will give a good signal to investors that cause an increase in company value.

The effect of Ownership Structure on Firm value is explained Theory of Asymmetric Information by Jensen and Meckling (1976) which mention that people who try to maximize their utility, there is good reason to believe that management will not always act in the best interests of the owner. Improved ownership structure by managers can minimize information gaps that can trigger actions in accordance with the interests of management and the interests of owners that can affect company value.

The Effect of Capital Structure on firm value is explained through Pecking Order Theory given by Myers (1984). Pecking order theory states that companies with high levels of profitability have low levels of debt, because companies with high profitability have abundant internal sources of funds. In this pecking order theory, there is no optimal capital structure. Specifically, companies have a preference order in the use of funds.

Some researchers have measured and analyzed the application of ownership structure to Firm value as did Mollah et al. (2012) which states that ownership structure have a significant positive impact on Firm value. In line with Byun (2013) find evidence that ownership structure get a positive impact and significant on valuation of the Firm.

Such an study explore to develop the results of previous research by developing a more representative model that is by including the variables of Dividend Policy, Structure of ownership, and Capital Structure of Firm value in one test model. The aim is to get a better and comprehensive understanding of the relationship between Dividend Policy, Structure of Ownership, Capital Structure of Firm value in the framework of developing a body of knowledge and strengthening the explanation of financial theories, primarily the theories of Bird in the Hand Theory, pecking order theory and Asymmetric information Theory)

Based above the description, this study aims to examine and explain the effect of Dividend Policy, Ownership Structure and Capital Structure on Firm value in Manufacture sub-sector companies listed on the Indonesia Stock 
Exchange for the period 2014-2018.

\section{Theoretical Review and Hypothesis Development}

\subsection{Dividend Policy}

Dividends represent company payments to shareholders for the profits. Determination of the amount of dividends is adjusted by dividend policy. Bird in the Hand Theory (Gordon, 1963) considers that investors prefer dividends because of certainty about the return invested and at the same time avoid risk. Tax Preference Theory states that investors prefer capital science because it can delay tax payments. Furthermore, signaling theory shows that dividends provide positive signals for investors because there is a perception that companies are able to maintain good performance (Bhattacharya, 1979).

\subsection{Ownership Structure}

Jensen \& Meckling (1976) states that Ownership Structure can be used to reduce agency costs stemming from agency problems. Ownership Structure (managerial ownership and institutional ownership) will align management interests with shareholders. Ownership Structure is an important mechanism to control the behavior of managers so that they act very carefully and work more efficiently to increase shareholder wealth.

\subsection{Capital Structure}

Funding Decisions According to Brealey et al. (2012: 6) is the second main responsibility of financial managers to raise funds needed by the company for investment and operations, therefore managers must be able to consider the composition of the use of debt with own capital. Kumar et al. (2012) that the funding decision is related to the company's decision in finding funds to finance investment and determine the composition of funding sources. The use of debt or leverage is external financing to finance company activities. Modigliani and Miller (1963) concluded that leverage will increase the value of a company because the cost of debt interest is the cost of reducing tax payments, so that the share of profits is more enjoyed by shareholders. Based on signaling theory, the use of debt will give a positive signal to investors about the manager's confidence in the success of an investment, so the existence of debt will increase firm value (Ross, 1977).

\subsection{Firm value}

Firm value is the stock market value, because firm value can provide maximum prosperity for shareholders if the company's share price increases. The higher the share price, the higher the prosperity for shareholders. To achieve firm value, investors generally leave their management to professionals. Sukoco (2013) states that firm value is justified by signaling theory, where firm value will provide a high value if it is supported by a good signal from the internal company. Maximizing firm value is very important for the company, because maximizing firm value also means maximizing the prosperity of shareholders which is an important thing that must be achieved by company management (Brigham and Daves, 2013). Maximizing the prosperity of shareholders can translates to maximizing the company's share price. Although the company has other goals, but maximizes the share price is the most important goal. Firm value according to Gitman (2006) is the actual value per share that will be received if all assets companies are sold at market prices. Firm value will be reflected in the price its shares. The market price of the company's shares formed between the buyer and seller when a transaction occurs is called the market value of the company, because it is the market price shares are considered a reflection of the true value of the company's assets.

\subsection{Hypothesis Development}

2.5.1 Effect of Dividend Policy on Firm value

The results showed that Dividend Policy affect Firm value, so companies need to apply dividend policy more to improve Valuation. Most of the practices of dividend policy lead to reduced risks related to debt.. The effect of dividend policy on firm value has been proven empirically by Pinkowitz (2006), Hussainey et al. (2011) and Saifi et al. (2015). Pinkowitz (2006) shows that dividend payout has a significant positive effect on firm value with the market to book ratio indicator. Hussainey et al. (2011) shows the positive influence between dividend income in the form of dividend yield and dividend payout on changes in stock prices. Saifi et al. (2015) show that the dividend policy in the form of Dividend Per Share, Dividend Equity Ratio and Dividend Yield has a significant positive effect on firm value with indicators of Price Earning Ratio and Tobin's Q. Based on the theoretical explanation and empirical study of this research, it is predicted that dividend policy will affect firm value in the following hypothesis formulation:

\section{Hypothesis 1: Dividend Policy has a significant effect on Firm value}

2.5.2 Effect of Ownership Structure on Firm value

The effect of ownership structure on firm value has been proven empirically by Iturriaga and Crisóstomo, (2010), Meca (2011), Mollah et al. (2012), Byun et al. (2013). Iturriaga and Crisóstomo, (2010) show that institutional 
ownership has a significant positive effect on firm value denoted by MBA (Market to Book Asset). Mollah et al. (2012) show that institutional ownership and public ownership have a significant positive effect on firm value with the Tobin'Q indicator. Byun et al. (2013) show that institutional ownership has a significant positive effect on firm value with the Tobin'Q indicator. Based on the description above, the research hypothesis is formulated as follows:

\section{Hypothesis 2: Ownership Structure has a significant effect on Firm value}

2.5.3 Effect of Capital Structure on Firm value

The effect of capital structure on firm value has been proven empirically by Itturiaga and Crisostomo (2010), Oluwagbemiga (2013) and Ghalandari (2013). Itturiaga and Crisostomo (2010) show that leverage has a significant positive effect on firm value with the market to book ratio indicator. Oluwagbemiga (2013) shows that the debt to equity ratio has a significant positive effect on firm value with the profitability indicator. Ghalandari (2013) shows that leverage has a significant negative effect on firm value with the market to book ratio indicator. Based on theoretical explanations and empirical studies, it is predicted that the capital structure will affect firm value in the formulation of the hypothesis as follows:

\section{Hypothesis 3: Capital Structure has a significant effect on Firm value}

\section{Research Methodology}

3.1 Types and Data Sources

This study aims to examine and explain the effect of exogenous variables (X) on endogenous variables (Y), so that the type of research used is explanatory research. According to Singarimbun and Effendi (1995: 5) explanatory research is research that explains the relationship between research variables and research hypotheses that have been formulated previously. The type of data required is secondary data that comes from companies that are taken as research samples.

In accordance with the type of data required is financial data documented by the company, the data collection method used is the documentation method. Researchers collected data from company financial report documents and annual reports, company firm value profiles, and IDX fact books for the period 2014 - 2018 and the Indonesian Capital Market Directory and are relevant to the needs and research objectives.

\subsection{Population and Samples}

The population in this study are manufacture companies listed on the Indonesia Stock Exchange between 2014 and 2018, amounting to 141 companies. Samples are subsets of certain group members that are part of the population, which are selected for analysis through sampling techniques that fit the research objectives.

The purposive sampling method is used with the criteria of listed companies and is still active in listing shares on the Indonesia Stock Exchange at least throughout the study period from 2014 to 2018, the company publishes financial statements continuously, share the dividend at least one in the period, and always profit. The selected data are 64 companies.

\subsection{Variables and Measurements}

This study uses three Independent variables namely (1) dividend policy is decision about how much of the profit will be distributed as dividends and the amount that will be counted as retained earnings. (2) Ownership Structure is the distribution of share ownership of a company (3) the composition of debt and equity as a source of corporate funding to finance investment. Dependent Variable is Firm value which is a form of share price by a company in a certain period.

Table 1. Measurement of Variables

\begin{tabular}{|l|c|c|c|}
\hline No & Variable & Indicator & Measurement \\
\hline 1 & Dividend Policy & Dividend per Share & Total dividends / Shares outstanding \\
\hline & & Dividend Payout Ratio & Dividend per share / Earning per share \\
\hline 2 & Ownership Structure & Managerial Ownership & Managerial share / Total Share \\
\hline & & Public Ownership & Public Share / Total Share \\
\hline 3 & Capital Structure & Total Debt Ratio & Total debt / Total assets \\
\hline 4 & & Debt Equity Ratio & Total debt / Total equity \\
\hline & Firm Value & Tobin'Q & Market Value / Book Value \\
\hline
\end{tabular}

3.4 Data Analysis Method

Data analysis using the PLS (Partial Least Square) analysis model using WarpPLS (Solimun et al., 2017).

The steps of the analysis using WarpPLS are as follows:

1. Designing a Structural Model (inner model). The design of structural models of relationships between latent variables in PLS is based on the formulation of the problem or research hypothesis

2. Designing a Measurement Model (outer model). The outer model in this research is formative, referring 
to the operational definition of variables

3. Constructing the Path diagram into the form of the inner model and outer model, so that the results are more easily understood, the results of the design of the inner model and the outer model, then expressed in the form of a path diagram.

4. Estimation methods (estimation) parameters using the least squares method (least square methods). The parameter estimation method in the PLS is the structural Equation Model quadratic method with nonparametric in the form of Partial Least Square. The calculation process is done by iteration, where the iteration will stop if a convergent condition has been reached.

5. Model Conformity Test by seeing the degree of concordance between the theoretical model variancecovariance matrix structure and the empirical variance-covariance matrix structure. If the two matrices are identical, then the theoretical model can be concluded perfectly accepted

\section{Results and Analysis}

4.1 Indicator Exploration Results for Each Variable

The results of this exploratory analysis in full the value of the factor load and component weights for each variable as in the following table 2 :

Table 2. Exploration Results of Indicators for Each Variable in the WarpPLS Model

\begin{tabular}{|c|c|c|c|}
\hline No & Variable & Loading/Weight & $\mathrm{p}$-value \\
\hline & \multicolumn{3}{|l|}{ Dividend Policy X1 } \\
\hline 1 & Dividend Per Share & 1.028 & $<0.001$ \\
\hline \multirow[t]{2}{*}{2} & Dividend Payout Ratio & -0.095 & 0.043 \\
\hline & \multicolumn{3}{|l|}{ Ownership StructureX2 } \\
\hline 1 & Managerial Ownership & 0.952 & $<0.001$ \\
\hline \multirow[t]{2}{*}{2} & Public Ownership & -0.273 & $<0.001$ \\
\hline & \multicolumn{3}{|l|}{ Capital StructureY1 } \\
\hline 1 & Total Debt Ratio & 1.978 & $<0.001$ \\
\hline \multirow[t]{2}{*}{2} & Debt Equity Ratio & -1.297 & $<0.001$ \\
\hline & \multicolumn{3}{|l|}{ Firm value Y2 } \\
\hline 1 & Tobin's Q & -0.074 & 0.090 \\
\hline 2 & Stock Price & 1.018 & $<0.001$ \\
\hline
\end{tabular}

Based on the results of the analysis in Table 2, it can be seen that the firm value variable, which is the Tobin's $\mathrm{Q}$, has a p-value that is not significant and also the Dividend Policy, Ownership Structure and Capital Structure that each of them has negative indicators weight are excluded from the model. The indicator weight negative indicators when entered will result in a confusing interpretation.

\subsection{Model fit and quality indices model WarpPLS}

In the WarpPLS analysis there is a fit model size and quality index, as in the following table Tabel 3. Model fit and quality indices model WarpPLS

\begin{tabular}{|c|c|c|c|c|}
\hline No & Model Fit with Quality Indices & Fit if: & Value & Decision \\
\hline 1 & (APC)Average path coefficient & The $\mathrm{P}<0.05$ & $\begin{array}{c}\text { And } \mathrm{P}=<0.001 \\
0.22\end{array}$ & Good \\
\hline 2 & (ARS)Average R-squared & The $\mathrm{P}<0.05$ & $\begin{array}{c}\text { And } \mathrm{P}=<0.001 \\
0.274\end{array}$ & Good \\
\hline 3 & (AARS)Average adjusted R-squared & The $\mathrm{P}<0.05$ & $\begin{array}{c}\text { And } \mathrm{P}=<0.001 \\
0.268\end{array}$ & Good \\
\hline 4 & (AVIF)Average block VIF & $\begin{array}{l}\text { Will be } \\
\text { acceptable if }<5, \\
\text { will be ideal }< \\
3.3\end{array}$ & 1.046 & Ideal \\
\hline 5 & (AFVIF)Average full collinearity VIF & $\begin{array}{l}\text { acceptable if }< \\
5, \text { ideally }<3.3\end{array}$ & 1.16 & Ideal \\
\hline 6 & (GoF)Tenenhaus GoF & $\begin{array}{c}\text { small }>0.1, \\
\text { medium }>0.25, \\
\text { large }>0.36\end{array}$ & 0.523 & Large \\
\hline 7 & (SPR)Sympson's paradox ratio & $\begin{array}{c}\text { ideal if } 1, \\
\text { acceptable if }> \\
0.7\end{array}$ & 1 & Ideal \\
\hline
\end{tabular}




\begin{tabular}{|c|c|c|c|c|}
\hline No & Model Fit with Quality Indices & Fit if: & Value & Decision \\
\hline 8 & (RSCR)R-squared contribution ratio & $\begin{array}{l}\text { ideal if } 1, \\
\text { acceptable if }=> \\
0.9,\end{array}$ & 0.9 & Good \\
\hline 9 & $\begin{array}{c}\text { acceptable if }= \\
>0.7\end{array}$ & 0.7 & Good \\
\hline 10 & $\begin{array}{c}\text { (SSR)Statistical suppression ratio } \\
\text { bivariate causality direction ratio }\end{array}$ & $\begin{array}{c}\text { acceptable if }= \\
>0.7\end{array}$ & 0.7 & \\
\hline
\end{tabular}

Table 3 shows that the model is fit, that is, all the fit and quality indices models are fulfilled. Thus the model is said to be good and can be used to explain the phenomena (systems) that are studied and can be used for hypothesis testing

\subsection{Hypothesis Testing Results}

Tabel 4. Hypothesis Testing Results

\begin{tabular}{|c|c|c|c|c|}
\hline Hypothesis & Relationship between Variables & Coefficient & P-value & Explanation \\
\hline 1 & Dividend Policy $\rightarrow$ Firm value & $0.683^{*}$ & $<0.001$ & Significant \\
\hline 2 & Ownership Structure $\rightarrow$ Firm value & $-0.052 \mathrm{~ns}$ & 0.176 & Non Significant \\
\hline 3 & Capital Structure $\rightarrow$ Firm value & $0.042 \mathrm{~ns}$ & 0.228 & Non Significant \\
\hline
\end{tabular}

Based on Table 4, the results of hypothesis testing are as follows:

The influence of Dividend Policy on Firm value get a coefficient 0.683 with P-value $<0.001$. Because the $\mathrm{P}$-value $<0.05$, and the positive coefficient that there is a significant and positive influence of Dividend Policy on Firm value. This means that the higher the Dividend Policy, the higher the Firm value will be. Hypothesis 1 of this study was accepted. Relationship between Ownership Structure and Firm value get coefficient -0.052 with Pvalue $=0.176$. P-value $>0.05$, and negative coefficient indicates that there is insignificant effect of Ownership Structure on Firm value. Thus, hypothesis 2 of this study was rejected. Effect of Capital Structure on Firm value get coefficient 0.042 and $\mathrm{P}$-value $=0.228$. P-value $>0.05$, and positive coefficient indicates Capital Structure insignificantly affect Firm value. Thus, hypothesis 3 of this study was rejected.

\section{Discussion}

5.1 Effect of Dividend Policy on Firm value

This study accept hypothesis 1 , because Dividend Policy significantly affect Firm value, coefficient number is 0.683 with P-value $<0.001$ were obtained. P-value $<0.05$, with positive direction of coefficient indicates that Dividend Policy affect Firm value significantly positive. This means that the higher the Dividend Policy, the significant positive impact on Firm value.

The results of this study are supported by several studies, among others: Pinkowitz (2006) which states that effective dividend policy via dividend payout results in an increase in the company's firm value. Furthermore Hussainey et al. (2011) states the implementation of dividend policy showing a positive and significant to Firm value. Saifi et al. (2015) in his research showing that dividend policy has a positive impact on Firm value marked by Tobin's Q. Esana and Darmawan (2017) in their study mention dividend policy affect firm value significantly positive.

Positive and significant improvement shows a strong impact between Dividend Policy and Firm value. Thus, the stronger or weaker Dividend Policy will directly affect the valuation. The results indicate that Firm value in manufacture companies in Indonesia refers to Bird in the hand theory. This means that the firm value of manufacture companies in Indonesia is formed on the basis that investors prefer dividends because of certainty about the return invested. Strong or weak dividend policy will significantly influence Valuation of the firm.

\subsection{Effect of Ownership Structure on Firm value}

Hypothesis 2 of this study was rejected, because the effect of Ownership Structure on Firm value get coefficient number of -0.052 with $\mathrm{P}$-value $=0.176$. P-value $>0.05$, with negative direction of coefficient indicates that Ownership Structure affect Firm value insignificantly.

The results of this study is not line with the research of Iturriaga and Crisostomo (2010) which shows that ownership structure via institutional has a effect on statistical positive significance on company value. These findings also contradict the research of Mollah et al. (2012) states that there is a significant positive relationship between Ownership Structure and company value so with Byun et al. (2013) states: ownership Structure has a positive effect on firm value significantly. Majority ownership has a positive effect on firm value.

The insignificant influence between Ownership Structure and Firm value in this study indicates that the empirical Ownership Structure has nothing to do in improving Firm value in manufacture companies on the Indonesia Stock Exchange. The results of the study indicate that Firm value in manufacture companies in Indonesia 
is not support Theory of Agency said by Jensen \& Meckling (1976) which mention Ownership Structure can be used to reduce agency costs stemming from agency problems.

\subsection{Effect of Capital Structure on Firm value}

Hypothesis 3 of this study was rejected, because of the influence of capital structure on Firm value, coefficient number is 0.042 with $\mathrm{P}$-value $=0.228$ were obtained. $\mathrm{P}$-value $>0.05$ with positive direction of coefficient indicates influence capital structure of Firm value insignificantly positive. This means capital structure will not give significant result on Firm value.

The results of this study do not support the research of Itturiaga and Crisostomo. (2010) which states that capital structure as measured by leverage have a positive and significant impact on the company's Firm value, meaning that an increase in the leverage will raise up the company's value. These findings contradict Oluwagbemiga's research (2013) that capital structure with indicators of debt equity ratio have a positive and significant effect on Firm value; and Ghalandari (2017) that capital structure has a statistically significant positive effect on Firm value as measured by market to book ratio indicators at significant levels. But the research in line with Machfiro and Sukoharsono (2012) mention Capital Structure has effect on the Firm Value insignificant even with opposite direction. Investors in Indonesia are not using capital structure to invest their money in Food and Beverage Company that listed in period 2008-2011. Because most investors are prefer to short-term profits in the form of capital gains than dividend.

The insignificant relationship between capital structures with Firm value in this study indicates that the capital structure empirically cannot always be used to improve Firm value in manufacture companies on the Indonesia Stock Exchange.

The results indicate that Firm value in manufacture companies in Indonesia refers to Modigliani Miller (1958) state that prove, with a set of very limiting assumptions, that the value of a firm is not affected by its capital structure. The results obtained by MM show that how company will finance its operations means nothing, so the capital structure is irrelevant.

\section{Conclusion}

Dividend policy as measured by the dividend per share has a significant influence with a positive direction on Firm value. The findings are in accordance with the opinion of bird in the hand by Gordon (1963) mention dividend policy will influence Firm value positively due to investors like dividend because of certainty of the return invested.

Ownership Structure has no significant effect on Firm value, this means that there is still a concentration of company ownership in the Manufacture Sector companies in Indonesia which are the research sample. The concentration of company ownership in Ownership Structure in companies in the manufacture sector in Indonesia is the sample of this study. This finding also indicates that the management of the company is still under control or is an extension of the majority shareholder, that is, by a corporate legal entity or a holding company that is controlled by certain families only through institutional ownership, so that company management will prioritize the interests of the majority shareholder by the entity legal company or holding company and family through institutional ownership compared to the interests of all shareholders.

Capital Structure has an insignificant positive effect on Firm value, this is because in this study capital structure - total debt ratio is insignificant as a determinant of the variable characteristics of Firm value - Stock Price. Increased capital structure shows an insignificant increase on Firm value.

\section{References}

Brealey, R. A., Myers, S. C., \& Marcus, A. J. (2012). Fundamentals of Corporate Finance.

Brigham, F.E., and Daves. R.P. 2013. Intermediate Financial Management. Eight Edition. Mc.Graw Hill.

Byun, et al. (2013). Ownership Structure, Intensive Board Monitoring, and Firm Value: Evidence from Korea. Asia-Pacific Journal of Financial Studies, (2013)42, 191-227.

Esana, R., \& Darmawan, A. (2017). Pengaruh Kebijakan Dividen Dan Keputusan Investasi Terhadap Nilai Perusahaan Serta Dampaknya Terhadap Profitabilitas (Studi pada Sub Sektor Industri Barang Konsumsi yang Terdaftar di BEI Periode 2006-2016). Jurnal Administrasi Bisnis (JAB)|Vol. 50 No. 6 September 2017|.

Ghalandari, Kamal. (2013). The moderating effect of growth opportunities on the relationship between capital structure and dividend policy and ownership structure with firm value in Iran: Case study of Tehran Securities exchange. Research of Journal Applied Sciences, Engineering and Technology, 5(4), 1424-1431.

Gitman, L. J. (2006). Principles of Managerial Finance, International Edition (Vol. 10th edition). Boston: Pearson Education

Gordon, M., \& Lintner, J. (1959). Distribution of Income of corporations among dividend, retained earnings and taxes. The American economic review, May.

Gordon, Myron J. (1963). Optimal Investment and Financing Policy. .Journal of Finance. 18 (2) 264-272. 
Hussainey, K., Mgbame, C.O., \& Chijoke-Mgbame, A.M. (2011). Dividend policy and share price volatility: UK evidence. The Journal of Risk Finance, 12(1), 57-68.

Iturriaga, F., \& Crisóstomo, V. (2010). Do Leverage, Dividend Payout, and Ownership Concentration Influence Firms' Value Creation? An Analysis of Brazilian Firms. Emerging Markets Finance \& Trade, 46(3), 80-94.

Jensen, M. C., \& Meckling, W. H. (1976). Theory of the firm: managerial behavior, agency cost and ownership structure. Journal of financial economics, 3(4), 305-360.

Lorca, C., Sánchez-Ballesta, J. P., \& García-Meca, E. (2011). Board effectiveness and cost of debt. Journal of business ethics, 100(4), 613-631.

Machfiro, S., \& Sukoharsono, E. G. (2012). The Effect of Financial Variables on The Company's Value (Study on Food and Beverage Companies that are listed on Indonesia Stock Exchange Period 2008-2011). Jurnal Ilmiah Mahasiswa FEB, 1(1).

Modigliani, F., \& Miller, M. H. (1958). The cost of capital, corporation finance and the theory of investment. The American economic review, 48(3), 261-297.

Modigliani, F., \& Miller, M. H. (1963). Corporate income taxes and the cost of capital: a correction. The American economic review, 53(3), 433-443.

Mollah et al. (2012). The influence Of Agency Costs on Dividend Policy in the Emerging Market: Evidence from the Dhaka Stock Exchange. www.bath.ac.uk, May.

Myers, S. C. (1984). Capital structure puzzle (No. w1393). National Bureau of Economic Research.

Oluwagbemiga, O. E. (2013). Perceived relationship between corporate capital structure and firm value in the Kenyan listed companies. Research Journal of Finance and Accounting, 4(19), 157-164.

Pinkowitz, L., Stulz, R., \& Williamson, R. (2006). Does the contribution of corporate cash holdings and dividends to firm value depend on governance? A cross-country analysis. The Journal of Finance, 61(6), 2725-2751.

Ross, S. A. (1977). The determination of financial structure: the incentive-signalling approach. The bell journal of economics, 23-40.

Saifi et al., (2015). The Effect of Corporate Governance and Investment Opportunity Set on Capital Structure, Dividend Policy, and Firm Performance (A Study on Go-Public Manufacturing Companies in Indonesia Stock Exchange). International Journal of Management and Administrative Sciences (IJMAS) (ISSN: 2225-7225), $3(2), 53-63$.

Singarimbun, M., \& Effendi, S. (1995). Metode Penelitian Survai Edisi Revisi. Jakarta: Lp3ES.

Solimun. (2011). Analisis Variabel moderasi dan Mediasi. Program Studi Statistika FMIPA Universitas Brawijaya, Malang.

Solimun, Fernandes, A.A.E., \& Nurjannah. (2017). Metode Statistika Multivariat Permodelan Persamaan Struktural (SEM) Pendekatan WarpPLS. UB Press, Malang.

Sukoco, H., Nasir, M., \& PRASETIONO, P. (2013). Analisis Pengaruh Debt to Equity Ratio, Profitabilitas, Firm Size, dan Likuiditas terhadap Nilai Perusahaan melalui Mediasi Dividend Payout Ratio (Studi pada Industri Manufaktur di Bursa Efek Indonesia Periode Tahun 2009-2011) (Doctoral dissertation, Diponegoro University). 